\title{
Wandering consolidation
}

\author{
Tatsuyuki Kawahara, ${ }^{1}$ Nobuaki Ochi, ${ }^{1}$ Katsuya Kato, ${ }^{2}$ Kentaro Shibamoto, ${ }^{2}$ \\ Yasunari Nagasaki, ${ }^{1}$ Nozomu Nakagawa, ${ }^{1}$ Hidekazu Nakanishi, ${ }^{1}$ Hiromichi Yamane, \\ Yasumasa Monobe, ${ }^{3}$ Nagio Takigawa ${ }^{1}$
}

\section{OPEN ACCESS}

${ }^{1}$ General Internal Medicine 4, Kawasaki Medical School, Okayama, Japan

${ }^{2}$ Diagnostic and Therapeutic Radiology, Kawasaki Medical School, Okayama, Japan ${ }^{3}$ Pathology, Kawasaki Medical School, Okayama, Japan

\section{Correspondence to}

Dr Nobuaki Ochi, General

Internal Medicine 4, Kawasaki Medical School, Okayama 700 8505, Japan;

placidus.aura@gmail.com

Received 22 May 2018 Revised 10 April 2019 Accepted 26 April 2019 Published Online First 29 May 2019

\section{CASE PRESENTATION}

A 47-year-old man developed chest pain and low-grade fever. He was diagnosed with pneumonia with parapneumonic pleural effusion using a chest X-ray image (figure $1 \mathrm{~A}$ ) and CT without contrast (figure 2A). Although he received azithromycin, followed by garenoxacin, imaging indicated worsening of the condition (figures $1 \mathrm{~B}$ and $2 \mathrm{~B}$ ). As haemoptysis was observed, he was referred to our hospital.

He had never smoked and had been previously healthy except for atrial fibrillation that had been successfully treated via catheter ablation, without complications, 5 months previously. Physical examination revealed normal percussion and auscultation findings for both lungs, a blood pressure of $110 / 60 \mathrm{~mm} \mathrm{Hg}$, peripheral oxygen saturation of $97 \%$ at room air, a heart rate of $88 /$ min without arrhythmia, a respiratory rate of 18 breaths $/ \mathrm{min}$ and a body temperature of $36.8^{\circ} \mathrm{C}$. Routine blood tests yielded no remarkable finding except a C reactive protein level of $30.2 \mathrm{mg} / \mathrm{L}$. Bronchoalveolar lavage and transbronchial lung biopsy of the apicoposterior segment of the left upper lobe (figures $1 \mathrm{C}$ and $2 \mathrm{C}$ ) were performed. The lavage fluid was clear and the cells included macrophages

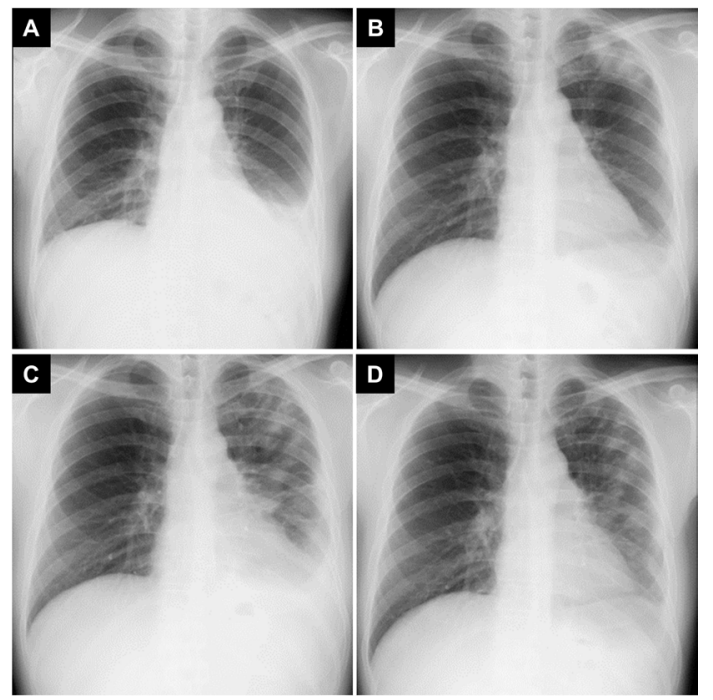

employer(s)) 2019. Re-use permitted under CC BY-NC. No commercial re-use. See rights and permissions. Published by BMJ.

To cite: Kawahara T, Ochi N, Kato K, et al. Thorax

2019:74:821-822.

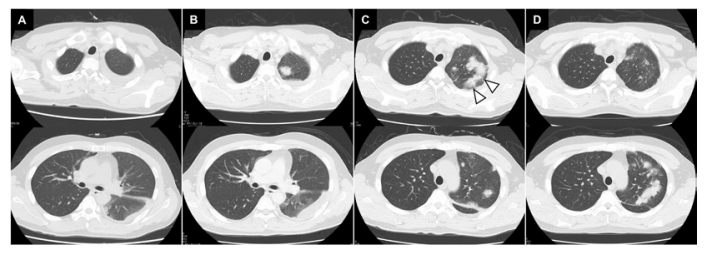

Figure 2 Chest CT scans obtained at the time of first onset of illness (A), at the time of the first visit to our hospital (B), on the day of bronchoscopic examination (C) and after prednisolone administration for 14 days (D). Arrowheads indicate the site for transbronchial lung biopsy.

(90.2\%), neutrophils (5.8\%), eosinophils (0.2\%) and lymphocytes $(3.8 \%)$. Histological examination revealed some tissue plugs within the lumina of the small airways, part-extending into the alveolar ducts and alveoli. Two weeks after bronchoscopic examination, we prescribed prednisolone $(0.5 \mathrm{mg} /$ $\mathrm{kg} /$ day) because the infiltration had progressed to the left lower lung field. Although the consolidation transiently regressed, it became slightly worse 2 weeks after treatment (figure 1D). Although we increased prednisolone (to $1 \mathrm{mg} / \mathrm{kg} / \mathrm{day}$ ), opacities in the left upper lobe migrated (figure 2D).

\section{QUESTION}

What is the differential diagnosis of this 'wandering consolidation'?

\section{ANSWER}

Because of the poor response to prednisolone, we performed a contrast-enhanced CT scan, which revealed severe stenosis of the left upper and lower pulmonary veins (PVs) (figure 3A). Three-dimensional rendered CT angiography and lung perfusion scintigraphy revealed a total perfusion deficit of the left lung (figure 3C and figure 4) compared with the enhanced CT performed before catheter ablation in which the left upper and lower PVs were both intact (figure 3B,D). Re-evaluation of the transbronchial lung biopsy specimen revealed fibrous thickening of the interlobular septum and oedematous thickening of the alveolar wall, with congestive capillary proliferation (capillary haemangiomatosis) (figure 5), compatible with PV occlusion. The patient underwent pericardial patch venoplasty of the left PV stenosis without any lung resection, and recovered well and appears to have survived with no adverse consequences. Although his condition is 

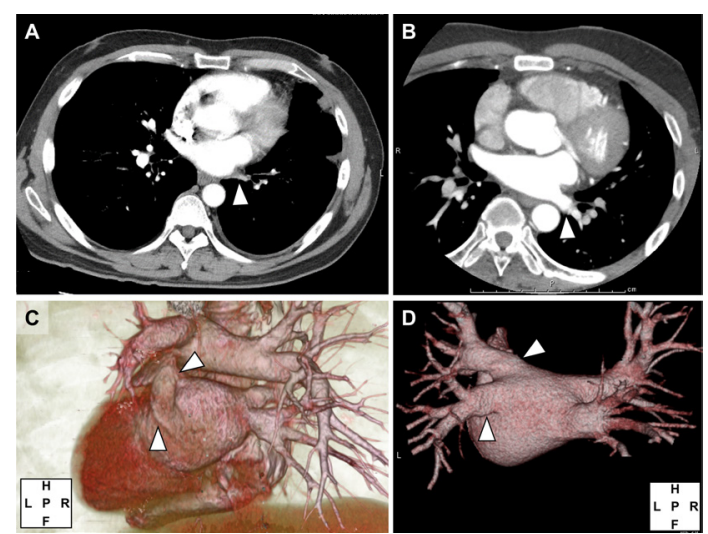

Figure 3 Chest contrast-enhanced CT and three-dimensional rendered $\mathrm{CT}$ angiography. $(\mathrm{A}, \mathrm{C})$ Images taken 22 days after prednisolone $(1 \mathrm{mg} /$ $\mathrm{kg} /$ day) administration. $(B, D)$ Images taken before catheter ablation. Arrowheads indicate left pulmonary veins.

not an extremely rare complication of catheter ablation, the clinical presentation and course of PV stenosis have not been well recognised. The common radiographic findings are consolidation and pleural effusion. Most patients were initially considered to have other pulmonary diseases such as bacterial pneumonia, lung cancer or a PE. A relatively small number of cases of PV stenosis have been diagnosed, as both the radiographic abnormalities and clinical symptoms are non-specific. ${ }^{1}$ Contrast-enhanced CT is most helpful in the diagnosis of PV stenosis. ${ }^{2}$

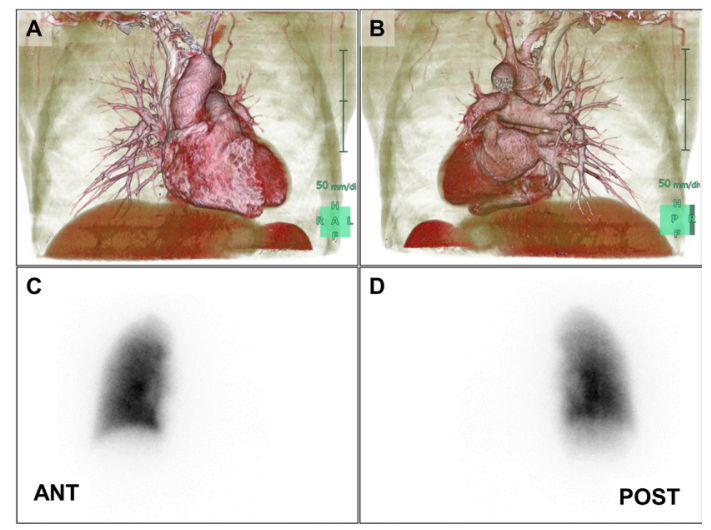

Figure 4 A three-dimensional rendered $C T$ angiogram and a perfusion lung scan were performed. $(A, C)$ Anterior (ANT) views. $(B, D)$ Posterior (POST) views. F, foot; $H$, head; $L$, left; $P$, posterior; $R$, right.

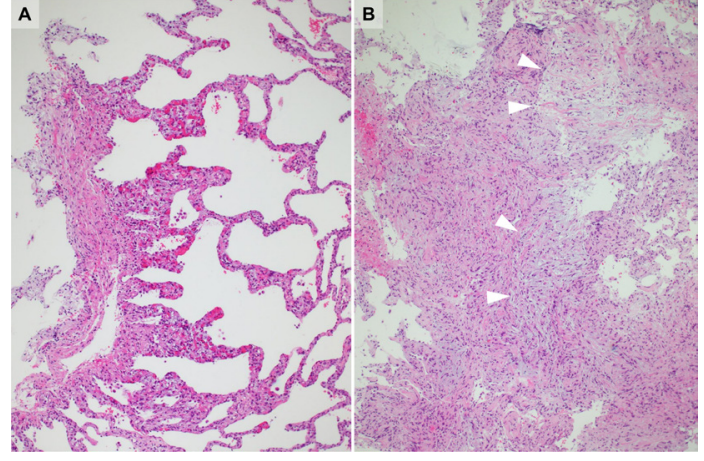

Figure 5 (A) Histologically, the transbronchial lung biopsy material revealed fibrous thickening of the interlobular septum and oedematous thickening of the alveolar wall with congestive capillary proliferation (capillary haemangiomatosis). (B) Cryptogenic organising pneumonialike oedematous fibrosis and diffuse luminal oedematous fibrosis (arrowheads) were evident in the peripheral air space.

When physicians encounter a patient with diffuse lung consolidation who has undergone catheter ablation, PV stenosis should be considered in the differential diagnosis. Based on the chest images alone, cryptogenic organising pneumonia might be misdiagnosed, as in the present case.

Contributors TK, NO and NT wrote the manuscript. YN, TK, NN, NO, HN, HY and NT treated the patient. KK and KS supervised the imaging analysis. YM supervised the histological diagnosis and capturing imaging.

Funding The authors have not declared a specific grant for this research from any funding agency in the public, commercial or not-for-profit sectors.

Competing interests None declared.

Patient consent for publication Obtained.

Provenance and peer review Not commissioned; externally peer reviewed.

Open access This is an open access article distributed in accordance with the Creative Commons Attribution Non Commercial (CC BY-NC 4.0) license, which permits others to distribute, remix, adapt, build upon this work non-commercially, and license their derivative works on different terms, provided the original work is properly cited, appropriate credit is given, any changes made indicated, and the use is non-commercial. See: http://creativecommons.org/licenses/by-nc/4.0/.

\section{REFERENCES}

1 Saad EB, Marrouche NF, Saad CP, et al. Pulmonary vein stenosis after catheter ablation of atrial fibrillation: emergence of a new clinical syndrome. Ann Intern Med 2003:138:634-8.

2 Packer DL, Keelan P, Munger TM, et al. Clinical presentation, investigation, and management of pulmonary vein stenosis complicating ablation for atrial fibrillation. Circulation 2005;111:546-54

3 Holmes DR, Monahan KH, Packer D. Pulmonary vein stenosis complicating ablation for atrial fibrillation: clinical spectrum and interventional considerations. JACC CardiovasC Interv 2009;2:267-76. 